\title{
UPAYA MENINGKATKAN HASIL BELAJAR SISWA MELALUI METODE PEMBELAJARAN PERMAINAN SIMULASI PADA MATA PELAJARAN PPKN SMP NEGERI 5 TEBING TINGGI
}

\author{
Yeni Sugianti \\ Surel : yeni.sugianti002@gmail.com
}

\begin{abstract}
ABSTRAK
Penelitian ini bertujuan untuk meningkatkan hasil belajar siswa pada mata pelajaran PPKn di kelas 7-1 SMP Negeri 5 Tebing Tinggi Tahun Ajaran 2016/2017. Jenis penelitian ini adalah Penelitian Tindakan Kelas (Action Research) dengan menggunakan Model Pembelajaran Konstruktivisme. Pelaksanaan penelitian ini dilakukan dalam dua siklus. Dan alat yang digunakan dalam pengumpulan data adalah tes ulangan harian dan lembar observasi untuk siswa dan peneliti. Subjek dalam penelitian ini adalah siswa kelas 7-1 SMP Negeri 5 Tebing Tinggi dengan jumlah 32 orang. Objek penelitian ini adalah penggunaan model pembelajaran Konstruktivisme dalam meningkatkan hasil belajar PPKn dikelas 7-1 SMP Negeri 5 Tebing Tinggi.
\end{abstract}

Kata Kunci : Permainan Simulasi, PPKn, Hasil belajar

\section{PENDAHULUAN}

Penggunaan

metode

pembelajaran yang tepat serta dapat melibatkan siswa aktif dalam pembelajaran tentu akan sangat mendukung tercapainya tujuan dari sebuah proses pembelajaran yakni terjadinya perubahan sikap atau ranah afektif pada siswa itu sendiri. Berbagai upaya dapat dilakukan oleh guru salah satunya dengan menerapkan model permainan simulasi (Simulation games) yang bersifat edukatif dalam pembelajaran yang diintegrasikan dengan materi pelajaran.

Hasil observasi awal yang peneliti lakukan tentang kegiatan guru dalam proses belajar di dalam kelas ditemukan proses pembelajaran yang diterapkan guru dengan cenderung menggunakan metode ceramah, guru kurang melakukan appersepsi, guru kurang memotivasi siswa, guru hanya berpegangan dengan buku paket, guru hanya memberikan catatan materi tentang hal-hal yang dianggap penting di papan tulis, guru kurang menarik dalam menyampaikan materi sehingga pembelajaran terasa membosankan, dan dalam pembelajaran guru tidak melakukan percobaan materi yang diajarkan.

Tujuan penilitian ini adalah untuk mengetahui penggunaan metode permainan simulasi dalam meningkatkan hasil belajar siswa pada mata pelajaran PPKn di kelas 7-1 SMP Negeri 5 Tebing Tinggi Tahun Pelajaran 2016/2017.

\section{METODE PENELITIAN}

Tempat penelitian adalah tempat yang digunakan dalam melakukan penelitian untuk memperoleh data yang diinginkan. Penelitian ini bertempat di SMP 
Negeri 5 Jl. Letda Sujono Kelurahan Teluk Karang Kecamatan Bajenis Tebing Tinggi Tahun Pelajaran 2016/2017.

Subyek penelitian adalah siswasiswi Kelas 7-1 SMP Negeri 5 kotaTebing Tinggi Tahun Pelajaran 2016/2017. Dengan keadaan siswa dalam kelas berjumlah 32 Siswa dimana laki-laki berjumlah 12 orang dan perempuan berjumlah 14 orang.

Waktu penelitian adalah waktu berlangsungnya penelitian atau saat penelitian ini dilangsungkan. Penelitian ini dilaksanakan pada bulan Agustus-Oktober 2016.

Pada implementasi pelaksanaan tindakan ini guru melakukan pelajaran di luar kelas dengan menggunakan panduan perencanaan yang telah dibuat. Penerapan metode permainan simulasi dilakukan dengan menugaskan kepada masingmasing kelompok untuk mendiskusikan materi yang diajarkan guru.Pada siklus ke dua ini juga, suasana pelajaran masing-masing kelompok di lingkungan sekolah dikondisikan agar tidak terlalu formal, maksudnya siswa bebas mengemukakan pendapatnya tentang materi ajar sesuai dengan kompetensi dasar yang ingin dicapai.

Peneliti melakukan penjumlahan nilai yang diperoleh siswa, yang selanjutnya dibagi dengan jumlah siswa yang ada di kelas tersebut sehingga diperoleh rata-rata tes formatif dapat dirumuskan :

$$
\overline{\mathrm{X}}=\frac{\Sigma x}{\Sigma \mathrm{N}}
$$

Dengan :

$\overline{\mathrm{X}} \quad=$ Nilai rata-rata

$\sum \mathrm{X}=$ Jumlah semua nilai siswa

$\sum \mathrm{N}=$ Jumlah siswa

Penelitian ini dapat dikatakan berhasil dan tidak perlu dilanjutkan kepada siklus berikutnya apabila hasil dari tes siswa yang berjumlah 32 orang telah sesuai dengan KKM yang ditentukan yaitu 70 atau tingkat ketuntasan kelas diatas $85 \%$ dari 32 siswa. Selain itu jika dilihat dari pengelolaan pelajaran, yaitu persentase pengelolaan pelajaran yaitu aktivitas guru dan aktivitas siswa diatas $85 \%$.

Sebelum penelitian dilakukan peneliti mengadakan survey para siklus pada minggu sebelumnya dan melakukan tes awal. Peneliti mengidentifikasi masalah melalui pengamatan proses belajar mengajar yakni rendahnya hasil belajar siswa kelas 7-1 SMP Negeri 5 Tebing Tinggi pada Mata Pelajaran PPKn. Kegiatan ini dilakukan dengan tujuan menyampaikan maksud mengadakan penelitian tindakan kelas dengan menerapkan model pembelajaran konstruktivisme untuk meningkatkan aktivitas siswa dalam proses pembelajaran. Pada pengamatan dilakukan dengan menggunakan lembar observasi aktivitas siswa dan menggunakan penilaian hasil evaluasi melalui ulangan harian. Jumlah siswa yang lulus pada hasil evaluasi yang dilakukan adalah sebanyak 8 siswa memenuhi kriteria nilai KKM dari 32 siswa dengan ketuntasan klasikal 25\%. 
Data Ulangan Harian berguna untuk mengetahui peningkatan hasilbelajar siswa setelah diterapkan metode pembelajaran permainan simulasi.

Pelaksanaan kegiatan belajar mengajar untuk siklus 1 dilaksanakan pada tanggal 25 Agustus 2016 di Kelas 7-1 dengan jumlah siswa 32 siswa. Dalam hal ini peneliti bertindak sebagai guru. Adapun proses belajar mengajar mengacu pada rencana pelajaran yang telah dipersiapkan. Pengamatan (observasi) dilaksanakan bersamaan dengan pelaksaaan belajar mengajar. Pada akhir proses belajar mengajar siswa diberi soal Ulangan Harian dengan tujuan untuk mengetahui tingkat keberhasilan siswa dalam proses belajar mengajar yang telah dilakukan. Adapun data hasil penelitian pada siklus 1 adalah sebagai berikut :

\section{Tabel Hasil Observasi Guru Pada Siklus 1}

\begin{tabular}{|c|c|c|c|c|}
\hline \multirow{2}{*}{ No } & \multirow{2}{*}{ Aspek yang diamati } & \multicolumn{2}{|c|}{ Penilaian } & \multirow{2}{*}{ Rata-rata } \\
\hline & & P1 & P2 & \\
\hline \multirow{3}{*}{ I } & $\begin{array}{ll}\text { A. Pendahuluan } & \text { Pengamatan KBM } \\
\text { 1. Melakukan apersepsi } \\
\text { 2. Menyampaikan tujuan pembelajaran } \\
\text { 3. Menghubungkan dengan pelajaran sebelumnya } \\
\text { 4. Mengatur siswa dalam kelompok-kelompok belajar }\end{array}$ & $\begin{array}{l}3 \\
2\end{array}$ & $\begin{array}{l}3 \\
2\end{array}$ & $\begin{array}{l}3 \\
3 \\
2\end{array}$ \\
\hline & $\begin{array}{ll}\text { B. } & \text { Kegiatan inti } \\
\text { 1. Mempresentasikan langkah-langkah model pembelajaran } & \text { konstruktivisme } \\
\text { 2. Membimbing siswa melakukan kegiatan } \\
\text { 3. Melatih keterampilan kooperatif } \\
\text { 4. Mengawasi setiap pasangan kelompok secara bergiliran } \\
\text { 5. Memberikan bantuan kepada pasangan kelompok yang } \\
\text { mengalami kesulitan }\end{array}$ & $\begin{array}{l}3 \\
3\end{array}$ & $\begin{array}{l}3 \\
3\end{array}$ & $\begin{array}{l}3 \\
3 \\
3\end{array}$ \\
\hline & $\begin{array}{l}\text { C. } \text { Penutup } \\
\text { 1. Membimbing siswa membuat rangkuman } \\
\text { 2. Memberikan evaluasi } \\
\text { 3. Memotivasi siswa }\end{array}$ & $\begin{array}{l}3 \\
3 \\
2\end{array}$ & $\begin{array}{l}3 \\
3 \\
2\end{array}$ & $\begin{array}{l}3 \\
3 \\
2\end{array}$ \\
\hline II & Pengelolaan Waktu & 2 & 2 & 2 \\
\hline III & $\begin{array}{ll} & \text { Antusiasme Kelas } \\
\text { 1. Antusias Siswa } \\
\text { 2. Antusias Guru }\end{array}$ & $\begin{array}{l}2 \\
3\end{array}$ & $\begin{array}{l}2 \\
3\end{array}$ & $\begin{array}{l}2 \\
3\end{array}$ \\
\hline & Jumlah & 39 & 39 & 39 \\
\hline
\end{tabular}


Yeni Sugainti : Upaya meningkatkan Hasil ....

Keterangan :

$$
\begin{array}{ll}
1 & =\text { Sangat Baik } \\
2 & =\text { Baik } \\
3 & =\text { Cukup } \\
4 & =\text { Kurang }
\end{array}
$$

Berdasarkan tabel di atas aspek-aspek yang mendapatkan kriteria kurang baik adalah melakukan apersepsi, Mengatur siswa dalam kelompok-kelompok belajar, Memberikan bantuan kepada pasangan kelompok yang mengalami kesulitan, pengelolaan waktu, Kelima aspek yang mendapat nilai kurang baik di atas, merupakan suatu kelemahan yang terjadi pada siklus 1 dan akan dijadikan bahan kajian untuk refleksi dan revisi yang akan dilakukan pada siklus 2. Hasil observasi berikutnya adalah aktivitas guru dan siswa.

Tabel Hasil Observasi Aktivitas Siswa Pada Siklus 1

\begin{tabular}{|l|l|c|c|}
\hline No & Aktivitas siswa yang diamati & $\begin{array}{c}\text { Presentase } \\
\text { Maksimal }\end{array}$ & $\begin{array}{c}\text { Presentase } \\
\text { Perolehan }\end{array}$ \\
\hline 1 & $\begin{array}{l}\text { Mendengarkan/ memperhatikan } \\
\text { penjelasan guru }\end{array}$ & 10 & 6.3 \\
\hline 2 & Membaca buku & 10 & 6.0 \\
\hline 3 & Keantusiasan siswa mengikuti pelajara & 10 & 5.5 \\
\hline 4 & $\begin{array}{l}\text { Siswa membentuk kelompok dengan } \\
\text { tertib }\end{array}$ & 10 & 5.3 \\
\hline 5 & $\begin{array}{l}\text { Melakukan diskusi tentang materi } \\
\text { pelajaran dengan teman } \\
\text { sekelompoknya }\end{array}$ & 10 & 5.5 \\
\hline 6 & $\begin{array}{l}\text { Siswa menuliskan dan mengerjakan } \\
\text { Lembar Kerja Siswa }\end{array}$ & 10 & 6.5 \\
\hline 7 & $\begin{array}{l}\text { Menuliskan dan menyampaikan hasil } \\
\text { diskusi }\end{array}$ & 10 & 5.7 \\
\hline 8 & $\begin{array}{l}\text { Mengajukan pendapat/ ide, bertanya } \\
\text { atau berkomentar kepada guru dan } \\
\text { siswa }\end{array}$ & 10 & 5.5 \\
\hline 9 & Merangkum pembelajaran & 10.5 \\
\hline 10 & Mengerjakan tes evaluasi & 10 & 5.0 \\
\hline Persentase Aktivitas Siswa & & 5 \\
\hline & Mena & 10 & 5 \\
\hline
\end{tabular}


Keterangan :

Nilai Persentase Kriteria

$$
\begin{array}{ll}
86-100 \% & \text { Baik } \\
70-85 \% & \text { Cukup } \\
1-69 \% & \text { Kurang }
\end{array}
$$

Berdasarkan hasil pengamatan pada siklus 1 menunjukkan bahwa penggunaan model pembelajaran Konstruktivisme dalam proses pembelajaran yang dilaksanakan, guru masih belum mengoptimalkan pembelajaran yang dilaksanakan. Hal ini dapat dilihat dari faktor kurangnya hasil belajar siswa. selain itu, dari hasil observasi yang dilakukan terhadap siswa juga menunjukkan kurangnya keaktifan dalam belajar PPKn dan masih perlu dilakukan tindakan selanjutnya. Pada siklus 1, secara garis besar kegiatan belajar mengajar dengan model pembelajaran konstruktivisme dilaksanakan belum dengan baik dan masih ke dalam kategori kurang. Aktivitas siswa yang dominan adalah siswa menuliskan dan mengerjakan Lembar Kerja Siswa (6,5 \%). Aktivitas lain yang presentasinya cukup besar adalah mendengarkan/ memperhatikan penjelasan guru $(6.3$ $\%)$. Kemampuan siswa/ kelompok dalam mengerjakan tugas, berargumen, keaktifan, kerjasama, motivasi dan lain-lain masih dinilai kurang. Pada saat guru menyuruh setiap kelompok mempresentasikan hasil diskusinya, ada siswa yang memperhatikan, ada yang asik sendiri dan ribut tidak memperhatikan. Kemudian siswa dan guru bersama-sama mengevaluasi kegiatan, selain itu garu juga memberikan penguatan, dorongan serta penghargaan bagi kelompok. Beberapa aspek yang mendapat nilai kurang baik di atas merupakan suatu kelemahan yang terjadi pada siklus 1 dan akan dijadikan bahan kajian untuk refleksi dan revisi yang akan dilakukan pada siklus 2 .

Tabel Hasil Tes Ulangan Harian Siswa Pada Siklus 1

\begin{tabular}{|c|c|c|c|c|c|c|c|c|c|}
\hline No & $\begin{array}{c}\text { Nomor } \\
\text { Responden }\end{array}$ & Skor & Nilai & Ket & No & $\begin{array}{c}\text { Nomor } \\
\text { Responden }\end{array}$ & Skor & Nilai & Ket \\
\hline 1 & 01 & 16 & 80 & $\mathrm{~T}$ & 17 & 017 & 8 & 40 & $\mathrm{TT}$ \\
\hline 2 & 02 & 14 & 70 & $\mathrm{~T}$ & 18 & 018 & 16 & 80 & $\mathrm{~T}$ \\
\hline 3 & 03 & 11 & 55 & $\mathrm{TT}$ & 19 & 019 & 14 & 70 & $\mathrm{~T}$ \\
\hline 4 & 04 & 11 & 55 & $\mathrm{TT}$ & 20 & 020 & 10 & 50 & $\mathrm{TT}$ \\
\hline 5 & 05 & 14 & 70 & $\mathrm{~T}$ & 21 & 021 & 10 & 50 & $\mathrm{TT}$ \\
\hline 6 & 06 & 11 & 55 & $\mathrm{TT}$ & 22 & 022 & 14 & 70 & $\mathrm{~T}$ \\
\hline 7 & 07 & 17 & 85 & $\mathrm{~T}$ & 23 & 023 & 16 & 80 & $\mathrm{~T}$ \\
\hline
\end{tabular}


Yeni Sugainti : Upaya meningkatkan Hasil ....

\begin{tabular}{|c|c|c|c|c|c|c|c|c|c|}
\hline 8 & 08 & 14 & 70 & $\mathrm{~T}$ & 24 & 024 & 17 & 85 & $\mathrm{~T}$ \\
\hline 9 & 09 & 14 & 70 & $\mathrm{~T}$ & 25 & 025 & 16 & 80 & $\mathrm{~T}$ \\
\hline 10 & 010 & 14 & 70 & TT & 26 & 026 & 14 & 70 & $\mathrm{~T}$ \\
\hline 11 & 011 & 14 & 70 & $\mathrm{~T}$ & 27 & 027 & 11 & 55 & TT \\
\hline 12 & 012 & 11 & 55 & TT & 28 & 028 & 14 & 70 & $\mathrm{~T}$ \\
\hline 13 & 013 & 17 & 85 & $\mathrm{~T}$ & 29 & 029 & 11 & 55 & TT \\
\hline 14 & 014 & 14 & 70 & $\mathrm{~T}$ & 30 & 030 & 14 & 70 & $\mathrm{~T}$ \\
\hline 15 & 015 & 8 & 40 & TT & 31 & 031 & 14 & 70 & $\mathrm{~T}$ \\
\hline \multirow[t]{7}{*}{16} & 016 & 11 & 55 & TT & 32 & 032 & 14 & 70 & $\mathrm{~T}$ \\
\hline & Jumlah & 237 & 1055 & & & Jumlah & 194 & 1190 & \\
\hline & \multicolumn{9}{|c|}{$\begin{array}{ll}\text { Jumlah Tuntas } & 21 \text { Siswa }(65,62 \%)\end{array}$} \\
\hline & \multicolumn{3}{|c|}{ Jumlah Yang Tidak Tuntas } & \multicolumn{6}{|c|}{11 Siswa $(34,37 \%)$} \\
\hline & \multicolumn{9}{|c|}{$\begin{array}{ll}\text { Jumlah Nilai } 2245 \\
\end{array}$} \\
\hline & \multirow{2}{*}{\multicolumn{3}{|c|}{$\begin{array}{l}\text { Jumlah Nilai maksimal ideal } \\
\% \text { ketercapaian skor }\end{array}$}} & \multicolumn{6}{|c|}{3200} \\
\hline & & & & $15 \%$ & & & & & \\
\hline
\end{tabular}

Keterangan:

Jumlah siswa yang tuntas $\quad: 19$

Jumlah siswa yang belum tuntas $\quad: 13$

Klasikal : Belum Tuntas

Rata-rata nilai siswa masih memiliki tingkat keberhasilan di bawah $85 \%(65,62 \%)$. Sehingga baik secara individu maupun klasikal hasil belajar siswa masih rendah, sehingga hasil belajar yang diinginkan belum tercapai. Oleh karena itu perlu dilakukan kembali untuk melanjutkan ke siklus 2. Pelaksanaan kegiatan belajar mengajar untuk siklus 2 dilaksanakan pada tanggal 1 September 2016 kelas 7-1 SMP Negeri 5 Tebing Tinggi dengan jumlah siswa 32 siswa. Dalam hal ini peneliti bertindak sebagai guru. Adapun proses belajar mengajar mengacu pada rencana pelajaran dengan memperhatikan revisi pada siklus 1, sehingga kesalahan atau kekurangan pada siklus 1 tidak terulang lagi pada siklus 2 . Pengamatan

(observasi) dilaksanakan bersamaan dengan pelaksanaan belajar mengajar.

Pada akhir proses belajar mengajar siswa diberi tes Ulangan Harian dengan tujuan untuk mengetahui tingkat keberhasilan siswa dalam proses belajar mengajar yang telah dilakukan. Instrumen yang digunakan adalah tes uraian. Selain melakukan observasi pada aktivitas siswa, dilakukan juga observasi pada kegiatan guru dalam pembelajaran PPKn melalui metode permainan simulasi. Hasil observasi berikutnya adalah observasi kegiatan guru oleh observator. Adapun data hasil penelitian pada siklus 2 adalah sebagai berikut : 
Tabel Hasil Observasi Guru Pada Siklus 2

\begin{tabular}{|c|c|c|c|c|}
\hline \multirow{2}{*}{ No } & \multirow{2}{*}{ Aspek yang diamati } & \multicolumn{2}{|c|}{ Penilaian } & \multirow{2}{*}{ Rata-rata } \\
\hline & & P1 & P2 & \\
\hline \multirow{3}{*}{ I } & \begin{aligned} & \multicolumn{1}{c}{ Pengamatan KBM } \\
& A. Pendahuluan \\
& 1. Melakukan apersepsi \\
& 2. Menyampaikan tujuan pembelajaran \\
& 3. Menghubungkan dengan pelajaran sebelumnya \\
& 4. Mengatur siswa dalam kelompok-kelompok \\
& belajar \end{aligned} & $\begin{array}{l}3 \\
3 \\
3 \\
3\end{array}$ & $\begin{array}{l}3 \\
3 \\
3 \\
3\end{array}$ & $\begin{array}{l}3 \\
3 \\
3 \\
3\end{array}$ \\
\hline & $\begin{aligned} & \text { B. } \text { Kegiatan inti } \\
& \text { 1. Mempresentasikan langkah-langkah model } \\
& \text { pembelajaran konstruktivisme } \\
& \text { 2. Membimbing siswa melakukan kegiatan } \\
& \text { 3. Melatih keterampilan kooperatif } \\
& \text { 4. Mengawasi setiap pasangan kelompok secara } \\
& \text { bergiliran } \\
& \text { 5. Memberikan bantuan kepada pasangan } \\
& \text { kelompok yang mengalami kesulitan }\end{aligned}$ & $\begin{array}{l}3 \\
3 \\
3 \\
3 \\
3\end{array}$ & $\begin{array}{l}3 \\
3 \\
3 \\
3 \\
3\end{array}$ & $\begin{array}{l}3 \\
3 \\
3 \\
3 \\
3\end{array}$ \\
\hline & $\begin{aligned} & \text { C. } \text { Penutup } \\
& \text { 1. } \text { Membimbing siswa membuat rangkuman } \\
& \text { 2. Memberikan evaluasi } \\
& \text { 3. Memotivasi siswa }\end{aligned}$ & $\begin{array}{l}3 \\
3 \\
3\end{array}$ & $\begin{array}{l}3 \\
3 \\
3\end{array}$ & $\begin{array}{l}3 \\
3 \\
3\end{array}$ \\
\hline II & Pengelolaan Waktu & 3 & 3 & 3 \\
\hline III & $\begin{array}{ll} & \text { Antusiasme Kelas } \\
\text { 1. } & \text { Antusias Siswa } \\
\text { 2. } & \text { Antusias Guru }\end{array}$ & $\begin{array}{l}3 \\
3\end{array}$ & $\begin{array}{l}3 \\
3\end{array}$ & $\begin{array}{l}3 \\
3\end{array}$ \\
\hline & Jumlah & 45 & 45 & 45 \\
\hline
\end{tabular}

Keterangan : Kriteria Nilai

$1=$ Tidak Baik $2=$ Kurang Baik

$3=$ Cukup Baik $4=$ Baik

Dari tabel di atas, dapat dilihat aspek-aspek yang diamati pada kegiatan belajar mengajar pada siklus 2 yang dilaksanakan oleh guru dengan menerapkan metode pembelajaran konstruktivisme mendapatkan penilaian baik dari pengamat adalah mempresentasikan langkah-langkah

metode pembelajaran permainan simulasi, membimbing siswa melakukan kegiatan. Penyempurnaan aspekaspek diatas dalam menerapkan metode pembelajaran permainan simulasi dengan meninjau ulang diharapkan dapat berhasil semaksimal mungkin. 
Yeni Sugainti : Upaya meningkatkan Hasil ....

Tabel Hasil Observasi Kegiatan Siswa Pada Siklus 2

\begin{tabular}{|c|c|c|c|}
\hline No & Aktivitas siswa yang diamati & $\begin{array}{l}\text { Presentase } \\
\text { Maksimal }\end{array}$ & $\begin{array}{l}\text { Presentase } \\
\text { Perolehan }\end{array}$ \\
\hline 1 & $\begin{array}{l}\text { Mendengarkan/ memperhatikan penjelasan } \\
\text { guru }\end{array}$ & 10 & 8.5 \\
\hline 2 & Membaca buku & 10 & 8.0 \\
\hline 3 & Keantusiasan siswa mengikuti pelajaran & 10 & 7.3 \\
\hline 4 & Siswa membentuk kelompok dengan tertib & 10 & 7.0 \\
\hline 5 & $\begin{array}{l}\text { Melakukan diskusi tentang materi pelajaran } \\
\text { dengan teman sekelompoknya }\end{array}$ & 10 & 7.4 \\
\hline 6 & $\begin{array}{l}\text { Siswa menuliskan dan mengerjakan Lembar } \\
\text { Kerja Siswa }\end{array}$ & 10 & 7.5 \\
\hline 7 & Menuliskan dan menyampaikan hasil diskusi & 10 & 7.0 \\
\hline 8 & $\begin{array}{l}\text { Mengajukan pendapat/ ide, bertanya atau } \\
\text { berkomentar kepada guru dan siswa }\end{array}$ & 10 & 7.0 \\
\hline 9 & Merangkum pembelajaran & 10 & 7.5 \\
\hline 10 & Mengerjakan tes evaluasi & 10 & 8.3 \\
\hline & Persentase Aktivitas Siswa & & 75.5 \\
\hline
\end{tabular}

Keterangan :

Nilai Persentase

Kriteria

$86-100 \%$

Baik

$70-85 \%$

Cukup

$1-69 \%$

Kurang

Setelah melakukan pembelajaran dengan menggunakan model pembelajaran Konstruktivisme maka guru melakukan ulangan harian 2 terhadap proses pembelajaran yang dilakukan pada akhir siklus 2 dapat dilihat pada tabel di bawah ini : 
SEJ VOLUME 7 NO. 2 JUNI 2017

Tabel Hasil Tes Ulangan Harian Siswa Pada Siklus 2

\begin{tabular}{|c|c|c|c|c|c|c|c|c|c|}
\hline No & $\begin{array}{c}\text { Nomor } \\
\text { Responden }\end{array}$ & Skor & Nilai & Ket & No & $\begin{array}{c}\text { Nomor } \\
\text { Responden }\end{array}$ & Skor & Nilai & Ket \\
\hline 1 & 01 & 20 & 100 & $\mathrm{~T}$ & 17 & 017 & 12 & 60 & TT \\
\hline 2 & 02 & 19 & 95 & $\mathrm{~T}$ & 18 & 018 & 20 & 100 & $\mathrm{~T}$ \\
\hline 3 & 03 & 18 & 90 & $\mathrm{~T}$ & 19 & 019 & 17 & 85 & $\mathrm{~T}$ \\
\hline 4 & 04 & 15 & 75 & $\mathrm{~T}$ & 20 & 020 & 15 & 80 & $\mathrm{~T}$ \\
\hline 5 & 05 & 20 & 100 & $\mathrm{~T}$ & 21 & 021 & 17 & 85 & $\mathrm{~T}$ \\
\hline 6 & 06 & 15 & 75 & $\mathrm{~T}$ & 22 & 022 & 17 & 85 & $\mathrm{~T}$ \\
\hline 7 & 07 & 20 & 100 & $\mathrm{~T}$ & 23 & 023 & 15 & 75 & $\mathrm{~T}$ \\
\hline 8 & 08 & 20 & 100 & $\mathrm{~T}$ & 24 & 024 & 16 & 80 & $\mathrm{~T}$ \\
\hline 9 & 09 & 19 & 95 & $\mathrm{~T}$ & 25 & 025 & 17 & 85 & $\mathrm{~T}$ \\
\hline 10 & 010 & 16 & 80 & $\mathrm{~T}$ & 26 & 026 & 17 & 85 & $\mathrm{~T}$ \\
\hline 11 & 011 & 18 & 90 & $\mathrm{~T}$ & 27 & 027 & 16 & 80 & $\mathrm{~T}$ \\
\hline 12 & 012 & 18 & 90 & $\mathrm{~T}$ & 28 & 028 & 15 & 75 & $\mathrm{~T}$ \\
\hline 13 & 013 & 19 & 95 & $\mathrm{~T}$ & 29 & 029 & 17 & 85 & $\mathrm{~T}$ \\
\hline 14 & 014 & 12 & 65 & TT & 30 & 030 & 16 & 80 & $\mathrm{~T}$ \\
\hline 15 & 015 & 14 & 75 & $\mathrm{~T}$ & 31 & 031 & 17 & 85 & $\mathrm{~T}$ \\
\hline 16 & 016 & 16 & 80 & $\mathrm{~T}$ & 32 & 032 & 20 & 80 & $\mathrm{~T}$ \\
\hline & Jumlah & 279 & 1400 & & & Jumlah & 310 & 1385 & \\
\hline & \multicolumn{3}{|c|}{ Rata-Rata } & 87,0 & & & & & \\
\hline & \multicolumn{3}{|c|}{ Jumlah Tuntas } & $30 \mathrm{~S}$ & va $(9$ & $75 \%)$ & & & \\
\hline & \multicolumn{3}{|c|}{ Jumlah Yang Tidak Tuntas } & $2 \mathrm{Sis}$ & ( & $5 \%)$ & & & \\
\hline & \multicolumn{3}{|c|}{ Jumlah skor } & 589 & & & & & \\
\hline & \multicolumn{3}{|c|}{ Jumlah Nilai maksimal ideal } & 640 & & & & & \\
\hline & \multicolumn{3}{|c|}{$\%$ ketercapaian Nilai rata-rata } & 92,0 & & & & & \\
\hline
\end{tabular}

Keterangan:

Jumlah siswa yang tuntas $\quad: 30$

Jumlah siswa yang belum tuntas $: 2$

Klasikal : Tuntas

Tabel Distribusi Hasil Tes Ulangan Harian Siswa pada Siklus 2

\begin{tabular}{|c|l|c|}
\hline No & \multicolumn{1}{|c|}{ Uraian } & Hasil Siklus 2 \\
\hline 1 & Nilai rata-rata tes Ulangan harian & 87,03 \\
2 & Jumlah siswa yang tuntas belajar & 30 \\
3 & Persentase ketuntasan belajar & 92,03 \\
\hline
\end{tabular}


Dari tabel diatas bahwa terdapat 2 orang siswa $(6,25 \%)$ atau yang belum tuntas belajar yaitu memiliki tingkat ketuntasan belajar dibawah 70 dan yang mencapai ketuntasan belajar sebanyak 30 orang siswa $(93,75 \%)$ dengan ketuntasan klasikal sebesar 92,03 \%. Dengan demikian dapat disimpulkan bahwa tingkat keberhasilan belajar siswa sudah melebihi nilai ketuntasan minimal yaitu 70 sehingga hasil belajar siswa sudah meningkat. Berdasarkan hasil pengamatan pada siklus 2 dapat terlihat guru sudah optimal dalam melaksanakan penerapan pembelajaran dengan metode pembelajaran permainan simulasi pada mata pelajaran PPKn materi perumusan dan penetapan UUD NKRI Tahun 1945. Saat melaksanakan diskusi dengan pasangannya, siswa sudah mulai aktif melaksanakan kegiatan diskusi dengan baik dan memecahkan masalah terhadap teks materi yang diberikan oleh guru.

\section{Pembahasan}

Pada siklus 1, secara garis besar kegiatan belajar mengajar dengan model pembelajaran konstruktivisme sudah dilaksanakan dengan baik, walaupun peran guru masih cukup dominan untuk memberikan penjelasan dan arahan, karena model tersebut masih dirasakan baru oleh siswa. Siswa terbiasa dengan diskusi kelompok besar yang membuat siswa menjadi pasif dan hanya mengandalkan temannya yang pintar. Namun secara umum proses pembelajaran berlangsung seperti yang direncanakan. aspek-aspek yang mendapatkan kriteria kurang baik adalah melakukan apersepsi, Mengatur siswa dalam kelompokkelompok belajar, Memberikan bantuan kepada pasangan kelompok yang mengalami kesulitan, pengelolaan waktu, memotivasi siswa dan siswa antusias. Kelima aspek yang mendapat nilai kurang baik di atas, merupakan suatu kelemahan yang terjadi pada siklus 1 dan akan dijadikan bahan kajian untuk refleksi dan revisi yang akan dilakukan pada siklus 2 .

Pada siklus 1 setelah dilakukannya tindakan kemudian diberikan evaluasi ternyata hasilnya meningkat dengan rata-rata nilai 70,15 dan tingkat ketuntasan belajar sebesar 65,62\%. Dalam siklus 1 dengan melihat rata-rata nilai dan tingkat ketuntasan belajar masih dinyatakan belum berhasil. Oleh karena itu dilanjutkan pada siklus 2.

Aktivitas siswa yang dominan adalah siswa menuliskan dan mengerjakan Lembar Kerja Siswa $(6,5 \%)$. Aktivitas lain yang presentasinya cukup besar adalah mendengarkan/ memperhatikan penjelasan guru (6.3 \%). Kemampuan siswa/ kelompok dalam mengerjakan tugas, berargumen, keaktifan, kerjasama, motivasi dan lain-lain masih dinilai kurang. Pada saat guru menyuruh setiap kelompok mempresentasikan hasil diskusinya, ada siswa yang memperhatikan, ada 
yang asik sendiri dan ribut tidak memperhatikan.

Pada siklus 2, merupakan perbaikan atau lanjutan pembelajaran yang telah diberikan pada siklus 1 . Pada siklus 2 ini didapat nilai ratarata 87,03 dan tingkat ketuntasan belajar $93,03 \%$. Hal ini berarti dengan menggunakan metode pembelajaran permainan simulasi dapat meningkatkan hasil belajar siswa pada materi perumusan dan penetapan UUD NKRI Tahun 1945, terlihat dari tingkat ketuntasan belajar siswa dan rata-rata nilai diperoleh 93,75.

Sedangkan untuk aktivitas siswa pada siklus 2Aktivitas siswa yang dominan adalahmendengarkan/ memperhatikan penjelasan guru $(8,5$ $\%)$. Aktivitas lain yang presentasinya cukup menegerjakan tes evaluasi $(8,3$ $\%)$. Pada saat guru menyuruh setiap kelompok mempresentasikan hasil diskusinya, hampir semua siswa serius meskipun ada yang kurang fokus dan tidak memperhatikan. Secara klasikal ketuntasan belajar sudah mencapai 90,90\%. Hasil ini sudah melebihi indikator yang ditentukan pada penelitian ini.

Hasil tes yang dilakukan pada siklus 2 menunjukkan hasil yang sangat memuaskan dimana sebesar $93,75 \%$ siswa atau dari 32 siswa yang telah tuntas sebanyak 30 siswa dan 2 siswa belum mencapai ketuntasan belajar. Dari hasil tes ini dapat dilihat bahwa hasil belajar dengan menggunakan metode pembelajaran permainan simulais telah mampu meningkatkan hasil belajar pada mata pelajaran PKKn sesuai dengan indikator yang telah ditentukan sehingga tidak perlu lagi dilanjutkan pada siklus berikutnya dan dikatakan berhasil.Gambaran peningkatan hasil belajar yang diperoleh setelah melakukan penelitian dengan menggunakan model konstruktivisme terlihat pada tabel berikut:

Tabel Peningkatan Hasil Belajar Siswa

\begin{tabular}{|c|c|c|c|}
\hline \multirow{2}{*}{ Keterangan } & \multicolumn{3}{|c|}{ Peningkatan Hasil Belajar } \\
\cline { 2 - 4 } & Pra siklus & Sikus 1 & Siklus 2 \\
\hline $\begin{array}{c}\text { Jumlah } \\
\text { siswa }\end{array}$ & 8 siswa & 21 siswa & 30 siswa \\
\hline $\begin{array}{c}\text { Persen } \\
\text { Ketuntasan }\end{array}$ & $25 \%$ & $65,62 \%$ & $93,75 \%$ \\
\hline
\end{tabular}

Lebih jelasnya peningkatan hasil belajar siswa dapat dilihat dari rata-rata nilai saat Tes Awal, Hasil
Siklus I, Hasil Siklus II seperti pada gambar grafik batang dibawah ini: 
Yeni Sugainti : Upaya meningkatkan Hasil ....

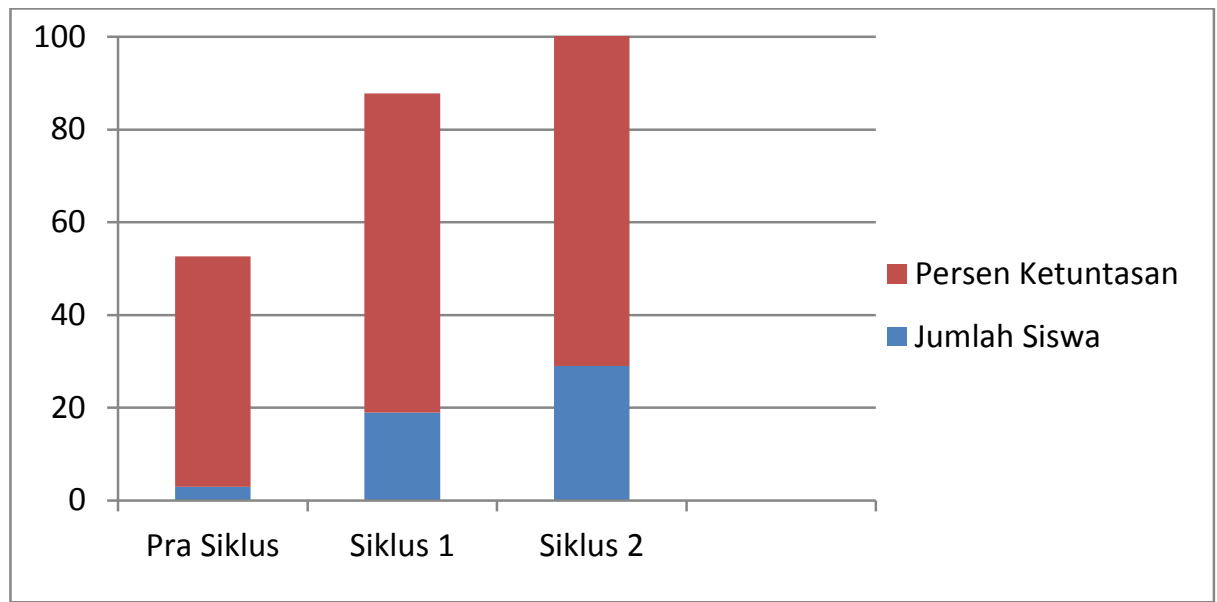

Gambar Peningkatan Hasil Ketuntasan Belajar Siswa

Dari tabel diatas menunjukkan peningkatan yang cukup drastis dari hasil belajar siswa kelas 7-1 SMP Negeri 5 Tebing Tinggi dapat dilihat pada hasil Pre Tes sebelum tindakan dilakukan, menunjukkan belum mencapai ketuntasan klasikal yaitu $25 \%$. Pada siklus I setelah menerapkan model pembelajaran konstruktivisme dalam pembelajaran meningkat menjadi $65,62 \%$, tetapi hasil belajar ini belum mencapai sasaran ketuntasan klasikal yang telah diterapkan sebelumnya. Kemudian setelah melakukan perbaikan pada siklus 2 hasil belajar siswa menunjukkan peningkatan yaitu 93,75\%. Hasil belajar ini menurut peneliti sudah mencapai sasaran penelitian $85 \%$ ketuntasan belajar klasikal sehingga peneliti tidak perlu merancang tindakan pada siklus selanjutnya.

Dengan demikian Pembelajaran PPKn dengan menggunakan metode pembelajaran permainan simulasi dikatakan berhasil meningkatkan hasil belajar siswa kelas 7-1 SMP Negeri 5 Tahun Pelajaran 2016/2017.

\section{SIMPULAN}

Dari hasil temuan penelitian tentang hasil belajar siswa dengan model konstruktivisme di kelas 7-1 SMP Negeri 5 Tebing Tinggi tahun pelajaran 2016/2017 berdampak positif dalam meningkatkan hasil belajar siswa. Hal tersebut dapat dilihat dari peningkatan persentase ketuntasan belajar siswa pada pra siklus $(25 \%)$, siklus $1(65,62 \%)$, dan siklus $2(93,75 \%)$.

\section{DAFTAR RUJUKAN}

Arikunto. 2010. Penelitian Tindakan Kelas. Jakarta : Bumi Aksara.

Arikunto, Suharsimi dan Suhardjo. 2008. Penelitian Tindakan Kelas. Jakarta: PT Bumi Aksara. Aqib, Zainal. et al. 2011. Penelitian Tindakan Kelas Untuk Guru SMP, SMA, SMK. Bandung: CV. Yrama Widya.

Budimansyah dan Suryadi. 2008. PKn dan Masyarakat Multikultural. Bandung: 
Program Studi Pendidikan

Kewarganegaraan, Sekolah

Pascasarjana, Universitas

Pendidikan Indonesia.

Depdiknas. 2007. Standar Isi

Kurikulum Berbasis Kompetensi.

Jakarta: Depdikbud.

Haryanto. 2011. Belajar dan

Pembelajaran. Bandung : PT

Remaja Rosdakarya.

Jensen, Eric. 2008. Brain Based

Learning. Yogyakarta : Pustaka Pelajar.

Komalasari, K. 2010. Pembelajaran

Kontekstual: Konsep dan Aplikasi. Bandung: PT. Refika Aditama.
Novitasari, Almi. 2008. Pendidikan Kewarganegaraan. Bandung: Erlangga.

Nurmalina \& Syaifullah. 2008. Memahami Pendidikan Kewarganegaraan. Bandung: Laboratorium PKn Universitas Pendidikan Indonesia.

Resmini, Novi. 2009. Simulasi Kreatif dalam pengajaran Bahasa Indonesia di Sekolah Dasar. Disertasi pada Jurusan Pendidikan Bahasa Indoesia dan Sastra Pasca Sarjana UPI Bandung : Tidak diterbitkan .

Slameto. 2010. Belajar dan FaktorFaktor Yang Mempengaruhi. Jakarta: Rineka Cipta. 